\title{
Optimizing sowing time for boosting productivity and nutritional quality of amaranth (Amaranthus cruentus L.) genotypes under Mediterranean climate
}

\author{
Paolo CASINI ${ }^{1,2}$, Gherardo BIANCOFIORE ${ }^{1}$
}

Received July 17, 2019; accepted February 13, 2020.

Delo je prispelo 17. julija 2019, sprejeto 13. februarja 2020.

Optimizing sowing time for boosting productivity and nutritional quality of amaranth (Amaranthus cruentus L.) genotypes under Mediterranean climate

Abstract: Currently, there is increasing interest in the cultivation of alternative grain crops, such as amaranth (Amaranthus cruentus L.) in Italy. However, few information exist for the most optimal sowing date (SD) of amaranth especially under rainfed conditions. A field-trial was conducted in Tuscany during 2018 to evaluate SD effects on amaranth genotypes ('Kharkov' and two new breeding lines coded 'A-61' and 'A-67'). The three SD were March 27 (first), April 20 (second), June 4 (third). Only the first and second SD coincided with increasing photoperiod. Cumulative Growing Degree Days (GDD) for ripening were 2282, 1990 and 1480 for the first, second and third $\mathrm{SD}$, respectively. Compared to the first two SD, ground-cover was $20 \%$ less from panicle formation in the third SD, therefore potentially less competitive towards weeds. A-67 was more "palatable" to the incidence of sugar beet flea beetle (Chaenoctema tibialis Illinger) from the earliest stages of growth. In contrast, 'Kharkov', was significantly less attacked by the insect over all three SD.

'Kharkov', demonstrated greater flexibility with stable yields of $1.3 \mathrm{t} \mathrm{ha}^{-1}$ for the first and second SD. In contrast, significant yield reductions ( 1.5 to $1.2 \mathrm{t} \mathrm{ha}^{-1}$, from the first to second $\mathrm{SD}$, respectively) were evident for both lines of amaranth in response to SD delay. Adverse effects of the third SD, included significant decline in yield, protein content and 1000 seed mass. In conclusion, amaranth, March-April SD may be recommended for obtaining optimal grain yield of amaranth along with making it successful as a viable alternative grain crop under agro-ecological conditions of Central Italy.

Key words: grain amaranth; breeding lines, Amaranthus cruentus; date of sowing; Central Italy
Optimizacija časa setve za povečanje produktivnosti in prehranske kakovosti genotipov zrnatega ščira (Amaranthus cruentus L.) v mediteranskih klimatskih razmerah

Izvleček: V zadnjem času narašča $\mathrm{v}$ Italiji interes za gojenje alternativnih zrnatih poljščin kot je zrnati ščir (Amaranthus cruentus L.), a je za najprimernejši čas setve (SD) v razmerah brez namakanja na razpolago le malo podatkov. $\mathrm{V}$ ta namen je bil v Toskani, v rastni sezoni 2018, izveden poljski poskus za ovrednotenje časa setve treh genotipov zrnatega ščira ( sorta Kharkov in dve novi žlahtniteljski liniji, označeni kot 'A-61' in 'A-67'). Izbrani so bili trije termini setve in sicer: 27. marec (prvi), 20. april 20 (drugi), 4. junij (tretji). Samo prvi in drugi termin setve sta soupadala $\mathrm{z}$ naraščajočo fotoperiodo. Komulativno število rastnih dni (GDD) do zorenja je bilo 2282, 1990 in 1480 za prvi, drugi in tretji čas setve. Primerjalno s prvima terminoma setve je bil pri tretjem sklop posevka za $20 \%$ manjši $\mathrm{v}$ času latenja, kar je zmanjšalo kompetitivnost proti plevelom. Linija 'A-67' je bila bolj palatibilna in bolj dovzetna za napad hrošča bolhača sladkorne pese (Chaenoctema tibialis Illinger) $\mathrm{v}$ začetnih fazah rasti. Nasprotno je bila sorta Kharkov značilno manj napadena s tem hroščem pri vseh treh datumih setve. Sorta Kharkov je pokazala večjo prožnost s stabilnim pridelkom, $1,3 \mathrm{tha}^{-1}$, za prvi in drugi termin setve. Nasprotno je bil pri obeh linijah zrnatega ščira značilen upad pridelka $\left(1,5\right.$ to $\left.1,2 \mathrm{t} \mathrm{ha}^{-1}\right)$ kot odziv na zakasnitev setve iz prvega na drugi termin. Negativni učinek tretjega termina setve je obsegal značilen upad pridelka, zmanjšanje vsebnosti beljakovin in zmanjšanje mase 1000 semen. Zaključimo lahko, da lahko obdobje marec-april priproročamo za setev zrnatega ščira za doseganje optimalnega pridelka zrnja in s tem uspešno uvedemo alternativno poljščino za pridelovanje zrnja v agroekoloških razmerah osrednje Italije.

Ključne besede: zrnati ščir; žlahtniteljske linije, Amaranthus cruentus; datum setve; osrednja Italija

1 University of Florence, Department of Agriculture, Food, Environment and Forestry, Florence, Italy

2 Corresponding author, e-mail: paolo.casini@unifi.it 


\section{INTRODUCTION}

There is an increasing focus on alternative crops, predominantly in areas where the cultivation of most common cereals (wheat, maize, barley, etc.) no longer provides a sufficient income for farmers due to low international selling prices. In addition, there is the necessity for boosting crops production leading to enhanced food safety levels under changing climate (Yarnia, 2010). In particular, increasing occurrences of drought in temperate areas necessitate irrigation for the most critical phases of spring-summer sown crops, which is often costly and difficult to implement. Hence, there is the need to look for alternative crops having higher grain potential under drought and water deficit conditions. Amaranth is cultivated in a wide variety of climates and cultivation systems in large areas, as well as at subsistence agriculture levels, either as a vegetable or for dried seeds (Borneo and Aguirre, 2008).

Different species of amaranth such as Amaranthus cruentus L., A. hypochondriacus L., A. caudatus L. and A. hybridus L., are receiving considerable research attention as grain and fodder crop owing to their diverse genetic makeup and superior agro-botanical characteristics (Cervantes, 1996). Some of the prime characteristics of these species include the high protein (15-18\%), lysine (5.2 $\mathrm{g}$ per $100 \mathrm{~g}^{-1}$ dry matter) and calcium $(0.37 \mathrm{~g}$ per $100 \mathrm{~g}^{-1}$ dry matter) (Petr et al., 2003). Moreover, these species have become distinguishable owing to absence of gluten and highly cherished by celiac patients (Ballabio et al., 2011).

Recently, a number of studies have been executed to determine the adaptability of amaranth in Italy primarily centered on the areas of Central and Southern Italy. First experiments have been performed to test the adaptation of amaranth plants, and qualitatively evaluate the grain (Massantini et al, 1987; Ercoli et al., 1987; Alba et al., 1997; Lovelli et al., 2005; Rivelli et al., 2008; Casini and La Rocca, 2014; Pulvento et al., 2015; El Gendy et al., 2018). The results of these tests highlighted an improved adaptability of $A$. cruentus, with a spring sowing, for seed production purposes. In the context of the provenances of the accessions tested in Italy, those derived from Mexico seem most adaptable. Not all aspects of the agronomic techniques have been addressed. Even if precise indications relating to the sowing density were obtained for A. cruentus (Casini and La Rocca, 2014), there is uncertainty with regard to the best sowing period, which is particularly important for a spring-summer crop.

Although amaranth is tolerant to drought (RoitnerSchobesberger et Kaul, 2013; Kauffman et Weber, 1990), the identification of the best SD in the Mediterranean environment, can aid plants in escaping, at least in part, periods with higher temperatures and scarcity of rains, especially coinciding with the formation of the panicle. In this phenological phase, possible water shortages and high temperatures negatively influence seed yield in $A$. cruentus (Mlakar et al., 2012). Within this species and with regard to drought tolerance, there is a certain degree of variability and the different accessions could be screened to choose the most suitable using the Van der Mescht and De Ronde (1993) method based on the accumulation of proline.

The choice of the most suitable sowing date has a direct effect on crop production. The emission of the inflorescence and flowering occur in optimum conditions, favoring maximum production (O'Brien et Price, 2008; Zubillaga et al., 2019). In a temperate Mediterranean environment, the spring sowing of amaranth cannot be performed too early, because the minimum temperature required for germination is approximately $12^{\circ} \mathrm{C}$ (Casini and La Rocca, 2015). Generally, the sowing period for this crop is similar to that of maize.

Each genotype reacts uniquely to the different sowing periods that directly influence the flowering and, above all, the ability to reach physiological maturation. In this context, the trends in photoperiod and temperatures play an important role in selecting the correct SD (Boote et al., 1994). Moreover, in temperate plains, amaranth has a tendency to wither with difficulty, hence the need to use medium-early cycle varieties to maximize yield and permit the complete maturation of the seeds.

The aim of the present research was to evaluate the effects of sowing date on grain yield, seed protein and mass in two new breeding lines of Amaranthus cruentus (A-61 and A-67), compared to a commercial variety ('Kharkov').

\section{MATERIALS AND METHODS}

Field experiment was carried out during 2018 in Tuscany, Central Italy at the "Centro per il Collaudo ed il Trasferimento dell'Innovazione di Cesa (Arezzo)" ( $43^{\circ}$ $18^{\prime}$ north; $11^{\circ} 47^{\prime}$ east, $246 \mathrm{~m}$ asl), on a neutral, loamysandy soil. Sampling of soil using a "W" shaped path were performed. The principle physical and chemical characteristics of the soil (depth of $20 \mathrm{~cm}$ ) resulted as follows: sand $36.4 \%$; loam $37.7 \%$; clay $25.9 \%$; total N $0.114 \%$; P (Olsen) 11 ppm; exchangeable Ca, Mg and K: 4250, 620 and $136 \mathrm{ppm}$, respectively. The experiment was carried out according to a RCB split-plot design with four replicates. The size of the overall plot was $18.0 \times 7.2 \mathrm{~m}$, which constituted the main factor, comprising two new breeding lines coded A-61 and A-67, as well as 'Kharkov', an Ukrainian commercial variety. The subplots $(2.4 \times 6.0 \mathrm{~m}$, 
four rows wide with $0.6 \mathrm{~m}$ row spacing) constituted four different sowing dates as follows: March 27; April 20, June 4 and June 20 (hereon referred to as the first, second, third and fourth SD).

Fertilizer treatment before seeding was as follows (Zubillaga et al., 2019): $76 \mathrm{~kg} \mathrm{ha}^{-1}$ of $\mathrm{N}$ as ammonium nitrate, and $100 \mathrm{~kg} \mathrm{ha}^{-1}$ of $\mathrm{P}_{2} \mathrm{O}_{5}$ as superphosphate. A seed quantity of $9 \mathrm{~kg} \mathrm{ha}^{-1}$ was used. In order to attain the planting density of 30 plants $\mathrm{m}^{-2}$, seedlings were thinned at the two-true leaf stage. Plots were hand-weeded twice (33 and 50 Days After Emergence [DAE]) during the growth cycle. The incidence of sugar beet flea beetle (Chaetocnema tibialis (Illiger, 1807), was estimated at emergence, and at the two-, four- and six-true leaf stage. Immediately after the last estimation, the seedlings were treated with the insecticide, deltamethrine $(50 \mathrm{ml}$ dissolved in $100 \mathrm{l}$ water).

The following field measurements were recorded: emergence, 2-, 4-, 6- and 10- true-leaf stages; early panicle appearance; full panicle appearance; early flowering; milky maturation, waxy maturation and maturation at $75 \%$. For the maturation stage, seed consistency was taken in consideration together with complete filling (nontranslucent endosperm).

The harvest was performed manually starting from September 7. The duration of maturation was accession dependent, and the different plots were harvested accordingly.

After drying the seeds to a standard humidity of $12 \%$, (airflow at $35{ }^{\circ} \mathrm{C}$ for $48 \mathrm{~h}$ ), the yield calculations were performed. A sample from a seed batch was used to determine the mass of 1000 seeds. Total protein was determined from the $\mathrm{N}$ content $(\mathrm{N} \times$ 6.25) using an Elemental Analyser EA FLASH 1112 of Thermo Fisher Scientific.

Day length records were provided by “Centro Inter- dipartimentale di Bioclimatologia-CIBIC" (University of Florence). Cumulative Growing Degree Days (GDD) were recorded from the first sowing (March, 27) to the last harvest period with a $\mathrm{T}_{\mathrm{z}}$ (base temperature) equal to $8{ }^{\circ} \mathrm{C}$ (Mujica et al, 1997) as follows:

$T_{m}$ is the daily mean temperature:

$$
G D D=\sum_{\text {days }}(T m-T z)
$$

Differences between response variables were assessed with COSTAT 6.45 software. Statistical differences were tested at $p \leq 0.05, p \leq 0.01$ or $p \leq 0.001$. The Tukey's HSD test was used to evidence significant differences between means and homogenous groups.

\section{RESULTS AND DISCUSSION}

The intense and persistent rains over March-April $(110 \mathrm{~mm})$ (Figure 1) led to a slight delay in the first sowing period compared to that predicted to be most suitable. Subsequently, this then led to a consequential delay of the remaining sowing periods envisaged. Even over the May-June period, the rains were of unusual frequency and intensity $(75 \mathrm{~mm})$, resulting in an extensive delay of the fourth SD, that was nonetheless carried out on June 20. This last SD was unsuccessful, due to high emergence failures. For this reason, only the first three sowing dates were considered in the statistical analysis of the results.

The increasing trend in photoperiod up to 65 Days After Sowing (DAS) the first SD, and up to 40 DAS from the second SD (Figure 2). In contrast, the entire growth cycle of the crop sown on the third SD was subjected

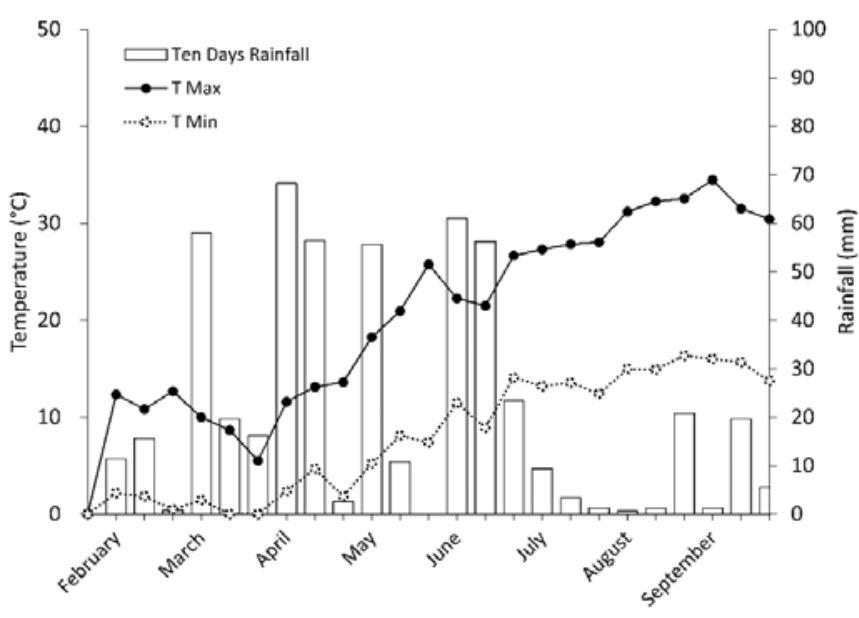

Figure 1: Temperature and rainfall recorded during the field experiment 


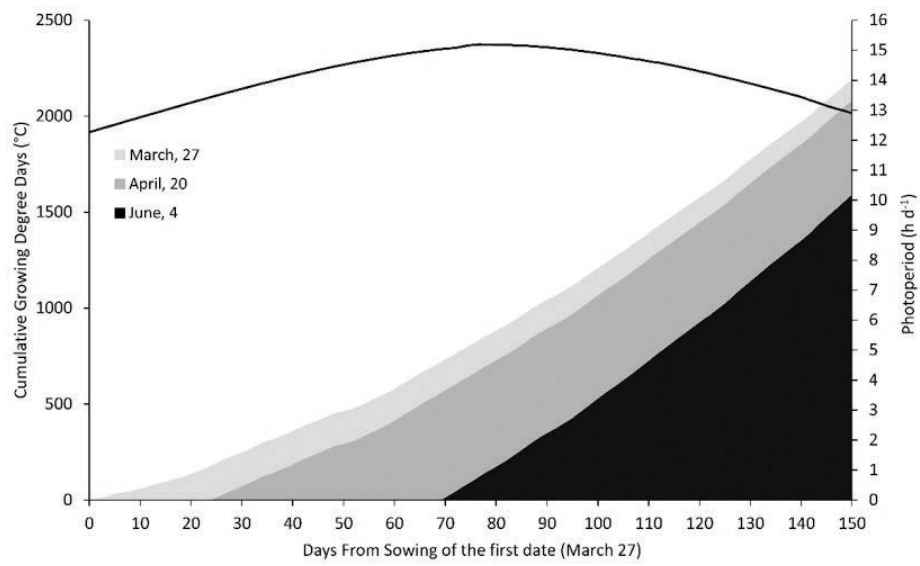

Figure 2: Cumulative Growing Degree Days (GDD) and day-length recorded during the field experiment according to the three sowing dates

Table 1: Analysis of variance of the growth stages

\begin{tabular}{|c|c|c|c|c|c|c|c|c|c|c|c|c|}
\hline Source of Variation & DF & Emergence & $\begin{array}{l}\text { Two true } \\
\text { leaves }\end{array}$ & & $\begin{array}{l}r \text { true } \\
\text { es }\end{array}$ & $\begin{array}{l}\text { Six } t r \\
\text { leave }\end{array}$ & & $\begin{array}{l}\text { Ten tru } \\
\text { leaves }\end{array}$ & & $\begin{array}{l}\text { Early } \\
\text { panicle }\end{array}$ & Panicle & Flowering \\
\hline Blocks & 3 & 1.63 & 29.44 & 141 & & 222.9 & & 73.22 & & 45.00 & 40.75 & 27.33 \\
\hline Date of sowing (D) & 2 & $515.06^{\star * *}$ & $1500.67^{\star * *}$ & 126 & $4.39^{* *}$ & 1120 & $39^{* *}$ & 2752.17 & $7^{* * *}$ & $1416.72^{\star \star \star x}$ & * 2067.17*** & * $1963.72^{* * *}$ \\
\hline Error D & 6 & 14.94 & 77.56 & 312 & & 196.9 & & 94.94 & & 67.50 & 38.83 & 57.83 \\
\hline Lines (L) & 2 & $12.72^{*}$ & 2.00 & 2.39 & & 17.39 & & 20.67 & & 9.72 & $32.67^{*}$ & $23.83^{\star}$ \\
\hline Error $L$ & 6 & 5.94 & 4.89 & 8.28 & & 10.61 & & 18.44 & & 23.83 & 18.00 & 13.50 \\
\hline $\mathrm{D} \times \mathrm{L}$ & 4 & 16.94 & 7.33 & 11.4 & & 5.28 & & 21.67 & & 12.94 & 6.67 & 20.78 \\
\hline Error D $\times L$ & 12 & 15.72 & 9.11 & 13.8 & & 42.72 & & 25.89 & & 40.17 & 36.67 & 28.33 \\
\hline Source of Variation & DF & $\begin{array}{l}\text { Milky } \\
\text { Maturity }\end{array}$ & $\begin{array}{l}\text { Waxy } \\
\text { Maturity }\end{array}$ & & Matur & & $\begin{array}{l}\text { Seed } \\
\text { hum }\end{array}$ & idity & Seed & yield & $\begin{array}{l}1000 \text { seeds } \\
\text { mass }\end{array}$ & Seed protein \\
\hline Blocks & 3 & 16.56 & 66.97 & & 1.42 & & 14.45 & & 1.57 & & 0.02 & 0.55 \\
\hline Date of sowing (D) & 2 & $4503.72^{* * *}$ & $4397.00^{\star}$ & & 7842.7 & $2^{* * *}$ & 88.21 & & 11.3 & $7^{\star *}$ & 0.03 & $29.32^{\star \star}$ \\
\hline Error D & 6 & 77.61 & 81.78 & & 2.83 & & 15.48 & & 1.94 & & 0.03 & 6.57 \\
\hline Lines (L) & 2 & 3.72 & 0.5 & & 0.06 & & 0.91 & & 0.01 & & 0.01 & $8.42^{\star}$ \\
\hline Error $L$ & 6 & 35.61 & 7.94 & & 2.83 & & 2.55 & & 0.43 & & 0.02 & 2.67 \\
\hline $\mathrm{D} \times \mathrm{L}$ & 4 & 17.78 & 1.00 & & 0.11 & & 4.78 & & 1.55 & & $0.03^{*}$ & 4.10 \\
\hline Error D $x L$ & 12 & 36.22 & 16.56 & & 5.67 & & 5.96 & & 0.72 & & 0.02 & 10.63 \\
\hline
\end{tabular}

${ }^{*}$ : significant at $p \leq 0.05 ;{ }^{* *}$ : significant at $p \leq 0.01{ }^{* * *}$ : significant at $p \leq 0.001$.

to decreasing photoperiod conditions. The three SD received 2282, 1990 and 1480 GDD, respectively.

The analysis of the variance, indicated significant differences largely attributable to the average effect of SD (Table $1 \& 2$ ). The variety effect was only significant with regard to the time of emergence, the emission of the panicle, flowering, and ground-cover with two-true leaves. For the 'Sowing date and Genotype' interaction, the only significant features at $p \leq 0.05$ were ground-cover of six- true leaves, and corresponding full maturation, as well as the weight of 1000 seeds.

Overall, the number of days required for the appearance of the panicle and flowering date decreased significantly from the first to the second SD, whilst the maturation period showed a progressive and significant decrease from the first to the third SD, respectively. In detail, the first appearance of the panicle occurred after approximately 66 DAE for the first SD, whilst the appearance of the panicle was anticipated by $15 \mathrm{~d}$ for the second 
Table 2: Analysis of variance of the ground cover recorded at different growth stages

\begin{tabular}{lllllll}
\hline Source of Variation & DF & Two true leaves & Four true leaves & Six true leaves & Ten true leaves & Early panicle \\
\hline Blocks & 3 & 37.00 & 0.75 & 47.22 & 505.56 & 333.33 \\
Date of sowing (D) & 2 & 48.39 & $162.67^{\star *}$ & 151.39 & 59.72 & 1666.67 \\
Error D & 6 & 157.83 & 41.33 & 81.94 & 406.94 & 1400.01 \\
Lines (L) & 2 & $13.56^{*}$ & 19.50 & 26.39 & 243.06 & 66.67 \\
Error L & 6 & 5.33 & 21.83 & 56.94 & 223.61 & 200.00 \\
D x L & 4 & 10.44 & 3.33 & $61.11^{*}$ & 406.94 & 216.67 \\
Error D $x$ L & 12 & 13.33 & 17.33 & 38.89 & 576.39 & 2516.67 \\
\hline \hline Source of Variation & DF & Panicle & Flowering & Milky Maturity & Waxy Maturity & Maturity \\
\hline Blocks & 3 & 2155.56 & 1941.67 & 1488.89 & 646.31 & 385.33 \\
Date of sowing (D) & 2 & 2866.67 & $4205.56^{* *}$ & $4310.22^{* *}$ & $3493.39^{*}$ & 1648.39 \\
Error D & 6 & 1444.44 & 816.67 & 777.78 & 1464.61 & 1816.50 \\
Lines (L) & 2 & 466.67 & 105.56 & 288.89 & 115.06 & 44.22 \\
Error $L$ & 6 & 377.78 & 583.33 & 511.11 & 508.94 & 463.33 \\
D x L & 4 & 166.67 & 344.44 & 361.11 & 394.44 & $476.78^{\star}$ \\
Error D $x$ L & 12 & 1722.22 & 1033.33 & 972.22 & & 706.89 \\
\hline
\end{tabular}

${ }^{*}$ : significant at $p \leq 0.05 ;{ }^{* *}$ : significant at $p \leq 0.01 ;{ }^{* *}$ : significant at $p \leq 0.001$.

SD. A similar trend was observed for flowering. In comparison to the $85 \mathrm{DAE}$ necessary for the flowering of the first SD, flowering occurred at $69 \mathrm{DAE}$ for second SD, on April 20. A significant shortening in time for maturation, in comparison for the first SD, was observed for the second SD $(-16 \mathrm{~d})$ but above all for the third SD (-36 d).

This trend can be attributed to the fact that amaranth is a quantitative short-day species (Gimplinger et al., 2007). This means that it can flower in long photoperiod conditions, but starts the anthesis phase early when plants are exposed to shorter photoperiods. An anticipation or shortening in both flowering and maturation dates, similar to what is observed in this experiment, was in line as reported by Henderson et al. (Henderson et al., 1998). The same authors suggests that this tendency may also be attributed to the higher temperatures recorded during the delayed sowing dates, and an accelerated increase in temperature units. It was observed for species such as amaranth, in which the rate of development is temperature dependent (Gardener et al, 1991).

As regards the period between the emergence and the flowering, it must be pointed out that the first two SD benefited from an increasing photoperiod of 2.7 and $1.7 \mathrm{~h}$, respectively. Simultaneously, all three amaranth lines, were on average, able to take advantage of GDD equal to 974,671 and $1021{ }^{\circ} \mathrm{C}$ for the first, second and third SD respectively. The photoperiod from flowering to maturation decreased for all SD but this was particu- larly evident from the second $\left(1305^{\circ} \mathrm{C}\right)$ to the third $(451$ $\left.474{ }^{\circ} \mathrm{C}\right) \mathrm{SD}$.

All three SD permitted amaranth to attain to full maturation, even if with different yields, as will be discussed. The results of Zubillaga et al. (2019) were corroborated by the present work, reporting a minimum 1600 1700 GDD necessary for the completion of the crop cycle. In the present experiment, the third SD benefited from a minor GDD $\left(1480{ }^{\circ} \mathrm{C}\right)$, thereby imposing a shortening of the phenological phases (Table 2). The present study verified A. cruentus as a species capable of attaining economically viable yields in a Mediterranean environment when compared to A. hypochondriacus (Casini and La Rocca, 2014). Excellent production yields were obtained under conditions of both $12 \mathrm{~h}$ of light (Bavec et Mlakar, 2002) and in the presence of less than $12 \mathrm{~h}$, equivalent to just under three months of cultivation, as was reported by Wu et al. (2000) and Whithead et al.(2002) of which a minimum of 342 GDD was necessary to permit an efficient accumulation of biomass (biomass build-up) for harvesting (Nyathi et al., 2018).

The data shown in Figure 3 illustrates the development of the ground cover corresponding to the different phenological phases. At the four- and six-true leaf stages, the ground cover was greater in the third SD compared to the first SD by an average of $8 \%$. This is attributable to the faster plant growth due to the higher average temperatures in that period. This greater coverage of the terrain can certainly be useful for the crop, in order to 
Table 3: Main growth stages, day length and Growing Degree Days (GDD) from emergence to flowering and from flowering to maturation

\begin{tabular}{|c|c|c|c|c|c|c|c|c|}
\hline Lines & $\begin{array}{l}\text { Date of } \\
\text { sowing }\end{array}$ & $\begin{array}{l}\text { Early panicle } \\
\text { appearance } \\
(\mathrm{DAE})^{1}\end{array}$ & $\begin{array}{l}\text { Flowering } \\
\text { date } \\
\text { (DAE) }\end{array}$ & $\begin{array}{l}\text { Maturation } \\
\text { date } \\
\text { (DAE) }\end{array}$ & $\begin{array}{l}\text { Day length } \\
\text { from emer- } \\
\text { gence to } \\
\text { flowering } \\
\text { (h) }\end{array}$ & $\begin{array}{l}\text { Cumulative } \\
\text { GDD }{ }^{2} \\
\text { from emer- } \\
\text { gence to } \\
\text { flowering } \\
\left({ }^{\circ} \mathrm{C}\right)\end{array}$ & $\begin{array}{l}\text { Day length } \\
\text { from flower- } \\
\text { ing to matura- } \\
\text { tion } \\
\text { (h) }\end{array}$ & $\begin{array}{l}\text { Cumulative } \\
\text { GDD } \\
\text { from flowering } \\
\text { to maturation } \\
\left({ }^{\circ} \mathrm{C}\right)\end{array}$ \\
\hline \multirow[t]{3}{*}{ A-61 } & March 27 & $67.5 \mathrm{a}$ & $85.3 \mathrm{a}$ & $150.0 \mathrm{a}$ & $12.3-15.0$ & 957 & $15.2-12.9$ & 1272 \\
\hline & April 20 & $52.0 \mathrm{bc}$ & $70.5 \mathrm{~b}$ & $134.0 \mathrm{~b}$ & $13.5-15.2$ & 682 & $15.0-12.5$ & 1305 \\
\hline & June 4 & $56.0 \mathrm{~b}$ & $69.5 \mathrm{~b}$ & $114.1 \mathrm{c}$ & $14.1-13.5$ & 1006 & $13.5-11.3$ & 474 \\
\hline \multirow[t]{3}{*}{ Kharkov } & March 27 & $65.5 \mathrm{a}$ & $84.0 \mathrm{a}$ & $150.3 \mathrm{a}$ & $12.3-15.0$ & 974 & $15.2-12.9$ & 1379 \\
\hline & April 20 & $49.8 \mathrm{bc}$ & $66.8 \mathrm{~b}$ & $134.0 \mathrm{~b}$ & $13.5-15.2$ & 649 & $15.1-12.5$ & 1353 \\
\hline & June 4 & $56.5 \mathrm{~b}$ & $69.5 \mathrm{~b}$ & $114.0 \mathrm{c}$ & $14.1-13.5$ & 1029 & $13.5-11.3$ & 451 \\
\hline \multirow[t]{3}{*}{ A- 67} & March 27 & $66.0 \mathrm{a}$ & $85.8 \mathrm{a}$ & $150.0 \mathrm{a}$ & $12.3-15.0$ & 992 & $15.2-12.9$ & 1272 \\
\hline & April 20 & $52.0 \mathrm{bc}$ & $70.5 \mathrm{~b}$ & $134.0 \mathrm{~b}$ & $13.5-15.2$ & 682 & $15.0-12.5$ & 1305 \\
\hline & June 4 & $56.3 \mathrm{~b}$ & $69.3 \mathrm{~b}$ & $114.0 \mathrm{c}$ & $14.1-13.5$ & 1029 & $13.5-11.3$ & 451 \\
\hline
\end{tabular}

Means followed by the same letter(s) are not different for $\mathrm{p} \leq 0.05 ; 1$ DAE: Days After Emergence. 2 GDD: Growing Degree Days.

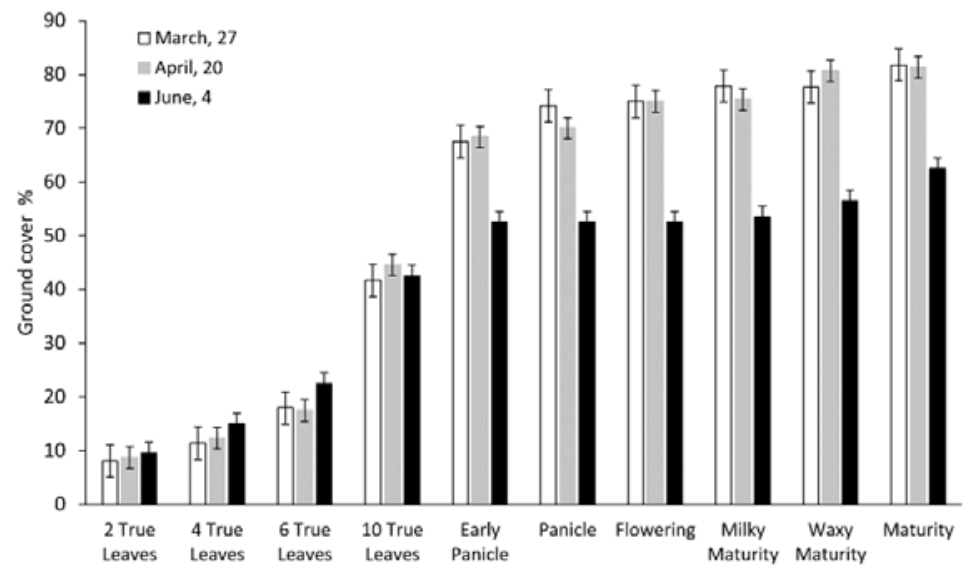

Figure 3: Ground cover according to the mean effect of the sowing date. Error bars represent the interval of the variability of the Tukey test. If the bars do not overlap, the difference between averages is significant at $p \leq 0.05$.

exert a better and more precocious competition against weeds. However, starting from the formation of the panicle, ground cover is significantly lower for plants sown on the third SD. From the initial $52 \%$ onto $63 \%$ at full ripening, there is a corresponding $20 \%$ less ground cover, compared to the mean of the first and second SD. The increasing temperatures, occurring in the last 5-6 phenological phases, reduced leaf development to permit the plants a tolerance to adverse climatic conditions. Similar results have been described by Zubillaga et al. (2019) in Argentina.
Particularly interesting are the data shown in Figure 4 , pertaining to the presence of the sugar beet flea beetle in the early stages of development according to the SD. The trend regarding the presence of this insect, contrary to what one might think about a species equipped with masticatory apparatus, differs according to the varieties. Even though all varieties exhibit the same level of attack in the emergence phase, the incidence of insect attack increases drastically up to $80 \%$ in the 'A- 61 ' genotype coinciding with the four-true leaf phase, and up to $48 \%$ in Kharkov. In the case of 'A-67', the incidence of 


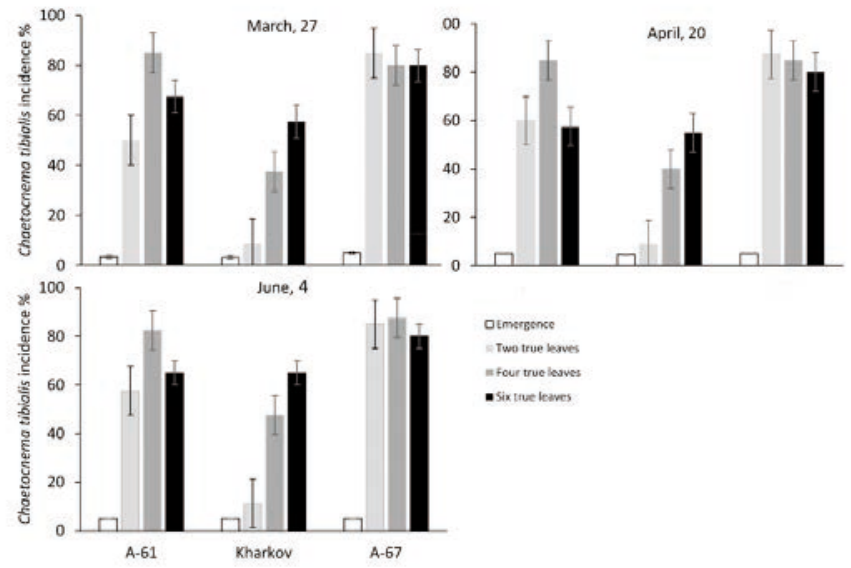

Figure 4: Incidence of sugar beet flea beetle (Chaetocnema tibialis Illiger) in different growth stages and date of sowing. Error bars represent the interval of the variability of the Tukey test. If the bars do not overlap, the difference between averages is significant at $p \leq 0.05$

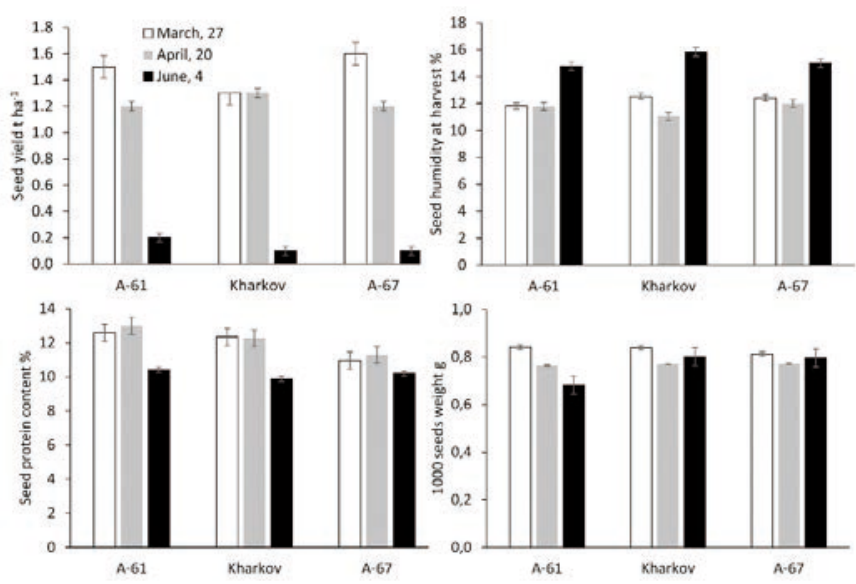

Figure 5: Seed yield, seed humidity at harvest and seed protein content of the varieties according to sowing date. Error bars represent the interval of the variability of the Tukey test. If the bars do not overlap, the difference between averages is significant at $p \leq 0.05$

the insect attack reaches $85 \%$ at the two-true leaf phase, maintaining this level until the six-true leaf phase, after which treatment with deltamethrine was implemented. Genotype 'A-67' was more "palatable" to the insect from the earliest stages of growth. In contrast, 'Kharkov', was significantly less attacked by the insect over all three SD. This data is important, as amaranth is characterized by displaying a slow growth in the initial phenological phases. Hence, in the case of 'Kharkov', being less "palatable" for sugar beet flea beetle is an advantage in the early more delicate phases of the cultivation, even towards overcoming weed competition.

Amaranth cultivated in the Mediterranean area is generally characterized by a higher humidity levels at harvest, compared to the standard humidity of $12 \%$, necessitating drying to permit storage under safe condi- tions. Due to the climatic conditions in the present study the problem was reduced. However, Figure 5 showed significant (for $p \leq 0.01$ ) differences in seed moisture at the time of harvesting. Humidity was significantly higher in the third SD (15.5\%), compared to an average of $12 \%$ for the remaining two SD. Higher humidity levels that exceed the standard, can be attributed to two concomitant factors. The first is the natural scalar maturation of the crop, also within the panicle of a single plant (acropetal trend). The second concomitant factor, relevant to the present experiment, was attributable to the delayed sowing that in time that hindered the complete filling of the seeds and the progressive loss of water. Seeds sown on the third SD were noted with many units of a darker, translucent endosperm, a sign of incomplete maturation and, therefore, a higher water content. 
The decrease in yield in relation to the delay in SD compared to the one considered most suitable, was also reported by other authors, and in environments other than the Mediterranean (Henderson et al., 1998; Yarnia, 2010; Troiani et al., 2004). The best yields were obtained with the first SD (for 'Kharkov' also for the second). This is attributable to the non-excessively high temperatures in the pre-flowering phase, as well as the increasing photoperiods that likely favored a higher rate of photosynthesis and plant development, resulting in a greater accumulation of reserve substances.

The data on seed protein content (Figure 5) highlighted a 2.5-3.0 \% reduction in e 'A-61' and 'Kharkov', from the first, and second to the third SD, respectively. A less sensitive reduction was observed for 'A-67'.

The mass of 1000 seeds was significantly reduced in relation to the delay in SD, only in the line 'A-61' (Figure 5). From the first to the third SD, there was a decrease from $0.842 \mathrm{~g}$ to $0.684 \mathrm{~g}$. The same effect was observed by Chaudari et al. (2009), for Amaranthus hypochondriacus.

\section{CONCLUSIONS}

Results of this experiment clearly highlighted the high sensitivity of grain amaranth, to different sowing periods. With regard to the vegetative phase, an excessive delay in sowing, impacted negatively on ground cover and, therefore, on the potential competition against weeds. This trend is particularly negative during the first 30-35 DAE, as amaranth has a very slow growth, and is subject to the effects of competition. Moreover, the different palatability of the sugar beet flea beetle to the different accessions can be useful in the early stages of development of the culture. In fact, in the area where the present experiment was performed, the presence of this insect was manifested very early from the emergence of the cotyledonous leaves. Therefore, if not promptly controlled, the insect is able to inflict serious damage. In some years it was necessary to repeat the treatment with deltamethrine, also at the six-eight-true leaf stage.

The present research reported for the first time, the necessary GDD values required to attain good production results for amaranth in Italy. In this context (Central Italy) we can affirm that a GDD between 2100 and 2300 produces the best productive potential in $\mathrm{A}$. $\mathrm{cru}$ entus, with completely ripe seeds and a lower harvest moisture content in comparison to later SD. The higher moisture content of the seeds of the third SD, would force the farmer to incur additional costs to reduce the values back to the standard 11-12\% requirement to ensure safe storage.

In conclusion, $A$. cruentus, introduced into the
Mediterranean environment of central Italy with a March-April SD, can be considered a viable alternative crop, even under conditions of non-irrigated cultivation.

\section{ACKNOWLEDGMENTS}

A special thanks to all the staff of the "Centro per il Collaudo ed il Trasferimento dell'Innovazione di Cesa (Arezzo)" for the competent and enthusiastic cooperation in conducting the experimental trail. This study was supported by Tozzi Green S.p.A., Italy.

\section{REFERENCES}

Alba, E., Polignano, G. B., Notarnicola, L. (1997). Yield stability in a set of Amaranthus entries in Souther Italy. Italian Journal of Agronomy, 1, 65-71.

Ballabio, C., Uberti, F., Di Lorenzo, C., Brandolini, A., Penas, E., Restani, P. (2011). Biochemical and immunochemical characterization of different varieties of Amaranth (Amaranthus L. ssp.) as a safe ingredient for gluten-free products. Journal of Agricultural Food Chemistry, 59(24), 12969-74. https:// doi.org/10.1021/jf2041824

Bavec, F., Mlakar, G. (2002). Effects of soil and climatic conditions on emergence of grain amaranths. European Journal of Agronomy, 17(2), 93-103. https://doi.org/10.1016/S11610301(01)00144-7

Boote, K. J., Bennet, J. M., Sinclair, T. R., Paulsen, G. M. (1994). Physiology and determination of crop yield, 601. Madison, WI: American Society of Agronomy, ISBN: 0-89118-122-9. https://doi.org/10.2134/1994.physiologyanddetermination

Borneo, R., Aguirre, A. (2008). Chemical composition, cooking quality, and consumer acceptance of pasta made with dried amaranth leaves flour. LWT-Food Science and Technolgy, 41, 1748-1751. https://doi.org/10.1016/j.lwt.2008.02.011

Casini, P., La Rocca, F. (2014). Amaranthus cruentus L. is suitable for cultivation in Central Italy: field evaluation and response to plant densities. Italian Journal of Agronomy, 9, 602, 166-175. https://doi.org/10.4081/ija.2014.602

Casini, P., La Rocca, F. (2015). Amaranto, manuale per la coltivazione, 1st ed., LoGisma, Vicchio, Italy, p. 104. ISBN 97888-97530-55-8

Cervantes, S. J. M. (1996). El amaranto: recurso forrajero Mexicano no aprocehado. Veterinaria Mexico, 17, 289-296.

Chaudhari, J. H., Raj, V. C., Rajeev, K., Srivastava Ahir, M. P. (2009). Effect of varying sowing date and row spacing on yield attributed of rabi grain amaranth (Amaranthus hypochondriacus L.) under south Gujarai conditions. Agricultural Science Digest, 29(2), 27-31.

El Gendy, A.N.G., Tavarini, S., Conte, G., Pistelli, L., Hendawy, S.F., Omer, E.A., Angelini, L.G. (2018). Yield and qualitative characterisation of seeds of Amaranthus hypochondriacus $\mathrm{L}$. and Amaranthus cruentus L. grown in Central Italy. Italian Journal of Agronomy, 13(1), 63-73. https://doi.org/10.4081/ ija.2017.993 
Ercoli, L., Masoni, A., Massantini, F. (1987). Influenza della fertilizzazione azotata sulla produzione di proteine da amaranto e chenopodio attraverso il frazionamento umido. $A g$ ricoltura Mediterranea, 117, 131-139.

Gardener, F. P., Brent, R., Mitchell, R. L. (1991). Physiology of crop plants. Cornell University Press, p. 400.

Gimplinger, D. M., Dobos, G., Schönlechner, R., Kaul, H. P. (2007). Yield and quality of grain amaranth (Amaranthus sp.) in Eastern Austria. Plant Soil Environment, 53, 105-112. https://doi.org/10.17221/2224-PSE

Henderson, T. L., Johnson, B. L., Schneiter, A. A. (1998). Grain amaranth seeding dates in the Northern Great Plains. Agronomy Journal, 90, 339-344. https://doi.org/10.2134/ag ronj1998.00021962009000030005x

Kauffman, C.S., Weber, L.E. (1990). Grain amaranth. Advances in New Crops, Janick J, Simon JE (eds). Timber Press: Portland, USA, pp. 127-139.

Lovelli, S., Pizza, S., Capolnio, T., Gherbin, P., Perniola, M. (2005). Analisi di crescita e valutazione agronomica di alcune specie erbacee a basso tenore di glutine. Proceedings of 34th Congress of the Italian Society of Agronomy. Foggia, Italy, 20-22 September, 298-299.

Massantini, F., Masoni, A., Ercoli, L. (1987). Potenzialità agronomiche dell'amaranto e del chenopodio come specie adatte al frazionamento umido: prove biennali. Agricoltura Mediterranea, 117, 31-41.

Mlakar, S.G., Bavec. M., Jakop, M., Bavec, F. (2012). The effect of drought occurring at different growth stages on productivity of grain amaranth Amaranthus cruentus 'G 6'. Journal of Life Science, 6(3), 283-286.

Mujica A., Berti, M., Izquierdo, J. (1997). El cultivo de amaranto (Amaranthus sp.): Producción, mejoramento genético y utilización. Departamento de Agricultura, División de Producción y Protección Vegetal. Toma, Italy, p. 97.

Nyathi, M. K., van Halsema, G. E., Annandale, J. G., Struik, P. C. (2018). Calibration and validation of the AquaCrop model for repeatedly harvested leafy vegetables grown under different irrigation regimes. Agricultural Water Management, 208, 107-119. https://doi.org/10.1016/j.agwat.2018.06.012

O’Brien, G. K., Price, M. L. (2008). Amaranth grain and vegetable types. ECHO Technical Note, www.echonet.org., http:// www.webcitation.org/78Wy2Wf6Z

Petr, J., Michalik, I., Tlaskalova, H., Capouchova, I., Famera, O., Urmiska, D., Tukova, L., Knoblochova, H. (2003). Exten- sion of the spectra of plant products for the diet in celiac disease. Czech Journal of Food Science, 21, 59-70. https:// doi.org/10.17221/3478-CJFS

Pulvento, C., Lavini, A., Riccardi, M., D’Andria, R., Ragab, R. (2015). Assessing amaranth adaptability in a Mediterranean area of South Italy under different climatic scenarios. Irrigation and Drainage, 64, 50-58. https://doi.org/10.1002/ ird.1906

Rivelli, A. R., Gherbin, P., De Maria, S., Pizza, S. (2008). Field evaluation of Amaranthus Species for Seed and Biomass Yields in Southern Italy. Italian Journal of Agronomy, 3, 225-229. https://doi.org/10.1002/ird.1906

Roitner-Schobesberger, B., Kaul, H.-P. (2013). Source capacity during flowering affects grain yield of amaranth (Amaranthus sp.). Plant Soil Environment, 59(10), 472-477. https:// doi.org/10.17221/528/2013-PSE

Troiani, R. M., Sánchez, T. M., Reinaudi, N. B. (2004). Optimal sowing dates of three species of graimbearing amaranth in the semi-arid argentine pampa. Spanish Journal of $A g$ riculture Research, 2(3), 385-391. https://doi.org/10.5424/ sjar/2004023-93

Van der Mescht, A., de Ronde, J. A. (1993). Drought-related protein synthesis in cotton. South African Journal of Plant and Soil, 10(1), 50-51. https://doi.org/10.1080/02571862.1 993.10634643

Whitehead, W.F., Carter, J., Singh, B. P. (2002). Effect of planting date on vegetable amaranth leaf yield, plant height, and gas exchange. Horticultural Science, 37(5), 773-777. https:// doi.org/10.21273/HORTSCI.37.5.773

Wu, H., Sun, M., Yue, S., Sun, H., Cai, Y., Huang, R., Brenner, D., Corke, H. (2000). Field evaluation of an amaranthus genetic resource collection in China. Genetic Resources and Crop Evolution, 47(1), 43-5. https://doi. org/10.1023/A:1008771103826

Yarnia, M. (2010). Sowing dates and density evaluation of amaranth (Cv. Koniz) as a new crop. Journal of Food, Agriculture and Environment, 8(2), 445-448.

Zubillaga, M. F., Camina, R., Oriolo, G. A., Barrio, D. A. (2019). Response of Amaranthus cruentus 'Mexicano' to nitrogen fertilization under irrigation in the temperature, semiarid climate of North Patagonia Argentina. Journal of Plant $\mathrm{Nu}$ trition, 42(2), 99-110. https://doi.org/10.1080/01904167.20 18.1549674 